\title{
Islamic Republic of Iran: Selected Issues Paper
}

This Selected Issues paper on the Islamic Republic of Iran was prepared by a staff team of the International Monetary Fund as background documentation for the periodic consultation with the member country. It is based on the information available at the time it was completed on January 11, 2010. The views expressed in this document are those of the staff team and do not necessarily reflect the views of the government of Iran or the Executive Board of the IMF.

The policy of publication of staff reports and other documents by the IMF allows for the deletion of market-sensitive information.

\author{
Copies of this report are available to the public from \\ International Monetary Fund • Publication Services \\ $70019^{\text {th }}$ Street, N.W. • Washington, D.C. 20431 \\ Telephone: (202) 623-7430 • Telefax: (202) 623-7201 \\ E-mail: publications@imf.org Internet: http://www.imf.org
}

\section{International Monetary Fund Washington, D.C.}




\section{INTERNATIONAL MONETARY FUND}

\section{ISLAMIC REPUBLIC OF IRAN}

\section{Selected Issues}

Prepared by Dominique Guillaume and Roman Zytek (MCD)

Approved by Middle East and Central Asia Department

January 11,2010

Contents

I. The Economics of Energy Price Reform in the Islamic Republic of Iran ..............................

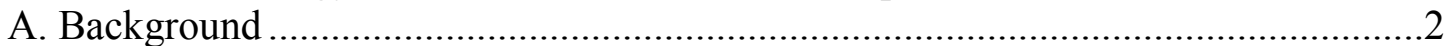

B. Benefits from Reforming the Energy Sector.........................................................

C. International Experience on the Impact of Energy Price Reform on Long-Term

Energy Efficiency ..........................................................................................

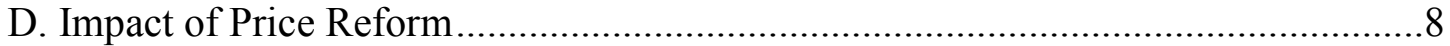

E. Measures to Mitigate the Impact of the Reform.......................................................11

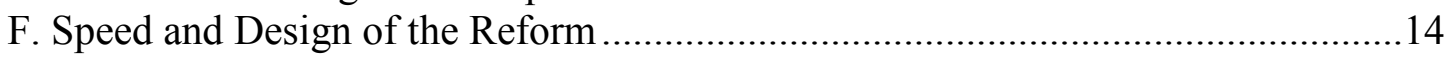

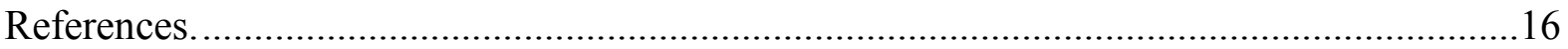

\section{Boxes}

1. Estimated Impact of Energy Price Reform on Households in Iran....................................

2. Impact of Energy Price Increase on GDP and Employment...........................................10

3. International Evidence of the Impact of Energy Price Reform on Economic

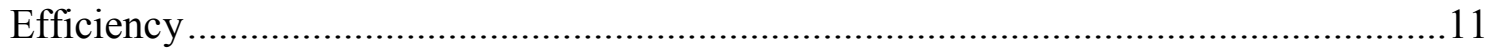

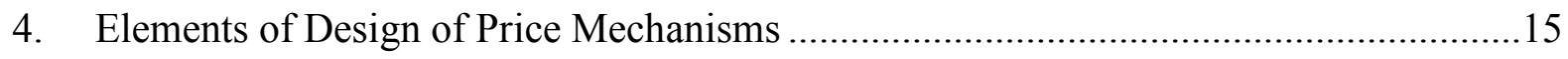

\section{Figures}

1. Retail Gasoline Price in Selected Middle East Countries..................................................

2. Growth in Electricity Consumption by Households in Selected Countries, 1995-2006 3

3. Comparison of Primary Energy Intensity and Electricity Conversion Efficiencies ..........4

4. Trends in Coal-to-Electricity Efficiencies.......................................................................6

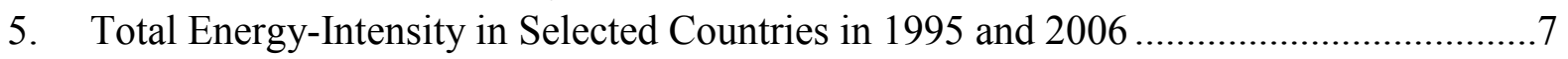




\section{The ECONOMICS OF ENERGy PRICE REForm In THE ISLAMIC REPUBLIC OF IRAN}

\section{A. Background}

1. The production of oil, gas and electricity plays a major role in the Iranian economy (World Bank, 2006a; Karbassi, et. al., 2007; Zamani, 2007). Iran has some of the largest proven reserves of crude oil and gas in the world. In 2008/09 crude oil and gas exports earned Iran an estimated 74 percent of foreign exchange receipts (24 percent of GDP) and financed rapid growth of imports. At the same time, oil revenues provided 65 percent of all fiscal revenues (16 percent of GDP). Value added in oil, gas and electricity generation accounted for almost 25 percent of GDP in 2008/09. Gas production is rising and gas exports have potential to surge multiple times in the next decade provided investments are made in the sector.

2. Economic policies in Iran have traditionally relied on the abundant availability of energy at very low price to finance the country's economic development (Farzanegan and Markwardt, 2009). Over the past decades, domestic fuel prices were among the lowest in the MENA region, at only a small fraction of their opportunity cost (Bhattacharyya and Blake, 2009) (Figure 1). In addition, prices were set differentiating by type of energy users (World Bank, 2007; IMF, 2008): households and production sectors in need of financial support such as agriculture or selected industries benefited from very low prices, while prices charged to other sectors have been set at higher levels, though well below opportunity costs.

Figure 1. Retail Gasoline Price in Selected Middle East Countries (In Rials per liter, Q1 2008)

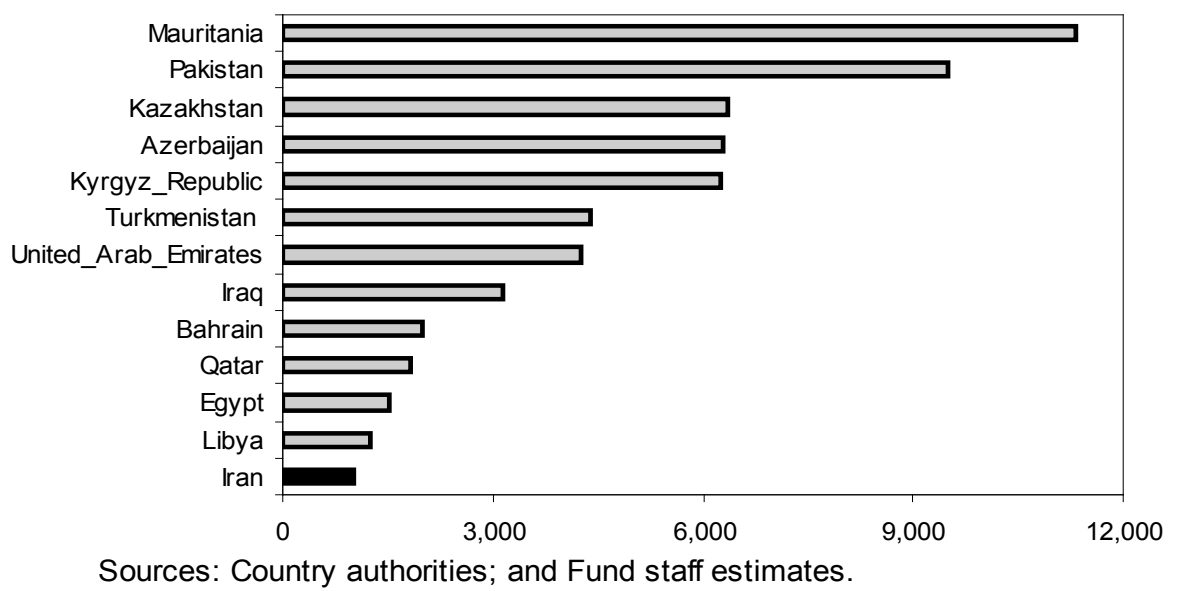

3. Low domestic energy prices have resulted in excessive use of energy (Figure 2). Iran's domestic energy use has been very high by international standards, and energy demand growth has exceeded the rate of growth of per capita income, in contrast to the experience of the majority of low and high income countries. Specifically, demand for gasoline in Iran grew by 9 percent per year in 1997-2006, over twice faster than per capita income. Energy use in per capita terms grew by about 4 percent per year in 1971-2002, four times faster than 
in low and high income countries. At 1.5 million barrels per day in 2002/03, Iran's oil consumption was similar to Spain's, which had a GDP six times higher than Iran's (Mehrara, 2007; Jafari and Baratimalayeri, 2008; Sobhiyah and Kashtiban, 2008; Bhattacharyya and Blake, 2009).

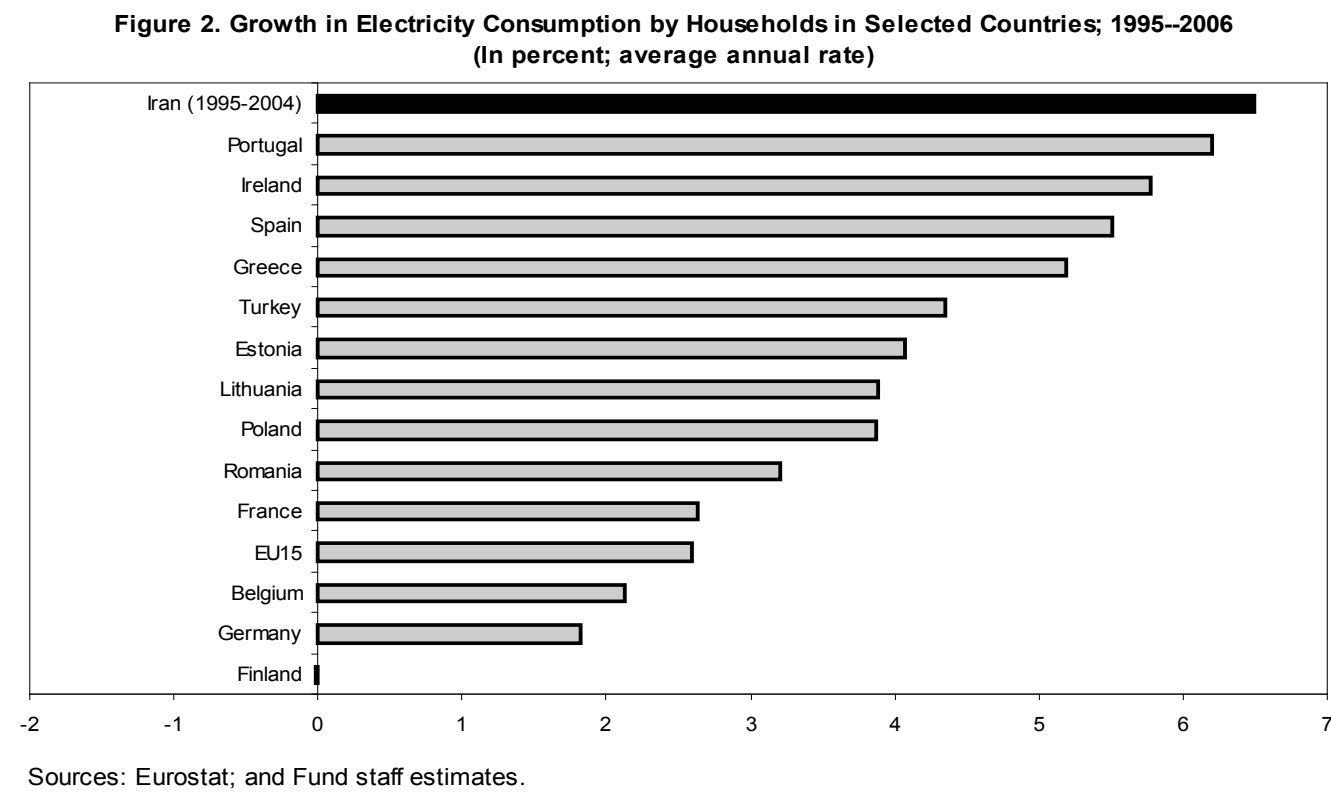

4. Low energy prices have encouraged the development of energy intensive industries, and inefficient energy use (Maruyama and Eckelman, 2009) (Figure 3). Iran's primary energy intensity in electricity production is 30 percent higher than the OECD average. Low costs of transport fuels encourage excessive driving and contribute to excessive capital investment in road and highway construction and to time lost in traffic congestion, causing pollution, environmental, and health related costs (World Bank, 2004, 2005a, 2006b; Shafie-Pour and Ardestani, 2007).

5. Low energy prices disproportionately benefit the rich and have a detrimental impact on the environment. Richer households who could afford larger housing, energy intensive appliances, and larger cars have benefited disproportionately from Iran's hydrocarbon wealth.

6. Low prices of hydrocarbon-based electricity generation have slowed down the development of alternative energies (Alnatheer, 2005). Iran has one of the greatest potential for solar energy, but the low prices of gas and oil have discouraged the development and deployment of energy saving technologies. 
Figure 3. Islamic Republic of Iran: Comparison of Primary Energy Intensity and Electricity Conversion Efficiencies

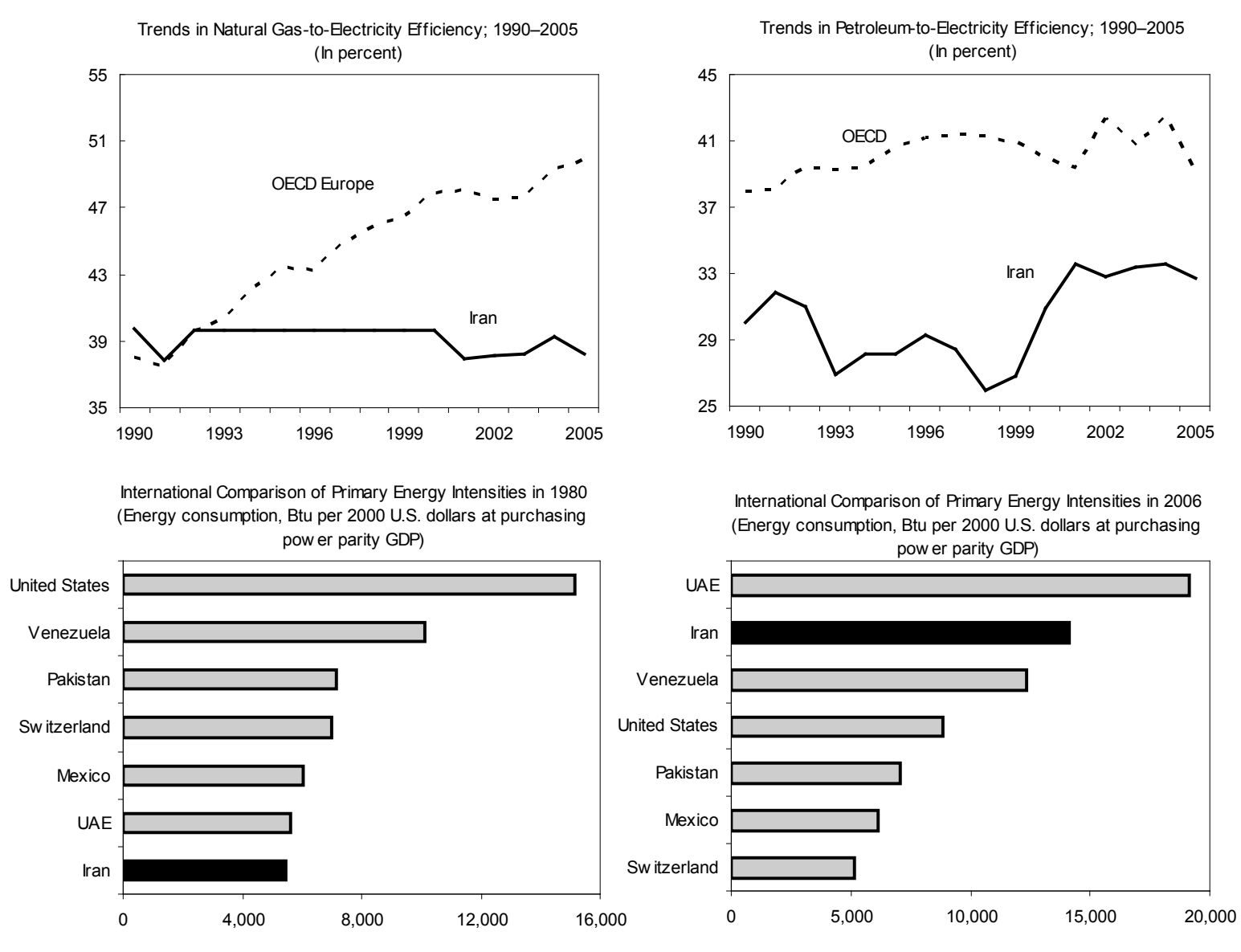

Sources:EIA; Eurostat; International Energy Annual 2006; U.S. Department of Energy; and Maruyama and Eckelman (2009).

7. The sustainability of Iran's energy production and use has become increasingly more fragile in recent years (Karbassi, et. al., 2007). Low prices have discouraged energy saving, leaving an insufficient surplus for investing in the production necessary to meet the rapidly growing demand for energy, in particular for electricity, gasoline and other refined products. As a consequence, in recent years Iran has become a net importer of gasoline.

\section{B. Benefits from Reforming the Energy Sector}

\section{Iran's economy would reap significant medium-to long-term benefits from} liberalizing energy prices. In the short-term, bringing energy prices to opportunity cost levels could strengthen Iran's current account and external reserve position and reduce the volatility in government capital spending. In the medium-term, energy allocation efficiency would improve significantly and energy intensity would decline, improving the overall competitiveness of the Iranian economy. 
9. Higher revenues resulting from the liberalization of energy prices would help generate the resources needed to maintain and expand energy production and support economic development and employment growth (Sari and Soytas, 2007; Belloumi, 2009). Gains in energy efficiency from the liberalization of oil prices would increase the amount of oil available for exports, thereby raising export revenues. At the same time, an increase in the domestic energy prices would sharply increase the profitability of the energy sector and provide the much needed revenues and incentives to finance research and development and investment in the sector, and in energy saving activities (Jannuzzi, 2005).

10. Higher energy prices would support Iran's diversification of energy sources (Awerbuch and Berger, 2003; Awerbuch and Sauter, 2005; Mehrara, 2007, 2008). Higher energy prices and a diversification of Iran's energy mix would help reduce the historically high volatility in domestic capital spending, GDP and inflation. Higher prices would also encourage energy saving among Iranian companies and households, enhancing competitiveness and benefiting the environment (World Bank, 2005a, 2006b; Mostafaeipour and Mostafaeipour, 2009).

11. Increased earnings from energy sales could allow the government to make the distribution of benefits from Iran's hydrocarbon resources more equitable, as more benefits could accrue to low income households that typically consume a relatively low share of heavily subsidized energy (Dodonov et. al., 2004; Freund and Wallich, 1996; Olivia and Gibson, 2008).

\section{International Experience on the Impact of Energy Price Reform on Long-Term Energy Efficiency}

12. Theoretical research shows that an increase in energy prices influences technological change both directly by inducing energy-saving innovations, and indirectly by inducing the development of new, less energy intensive equipment (Kratena, 2007). Okushima and Tamura (2009) decompose aggregate developments in energy intensity into a technological change component and a structural change component that reflects change in the output structure following a price shock.

13. The main lessons from empirical studies on energy price reform are that:

- $\quad$ Large increases in energy prices reduce energy consumption. While demand for energy is relatively price inelastic for small price changes, the very large price increases needed to bring prices to international levels in many reforming countries produce a material fall in energy demand and energy intensity. For instance, in Nigeria the long-run price elasticity for aggregate energy demand was estimated at minus 10 percent. For petroleum products, a 5 percent increase in the price of aggregate petroleum products was estimated to reduce per capita petroleum products consumption by about 1 percent (Iwayemi et. al., 2009). 
- $\quad$ Increasing energy prices reduces energy intensity. For instance, energy intensity fell over time after China deregulated energy prices in 1985-2004 (Zhao, 2001; Hang and Tu, 2007). Similarly, energy intensity has declined in transition economies after energy prices were liberalized in 1990s (Cornillie and Fankhauser, 2004).

- $\quad$ Reducing energy intensity takes time. While Poland had managed to reduce its overall energy intensity by 46 percent over 1989-2002, other Eastern European countries were less successful (Figure 4). In 2002, more than 15 years after reforms were initiated, energy intensity in Hungary was about three times higher than the corresponding figure for the European Union, while intensities for the Slovak Republic and the Czech Republic were about five times higher (Figure 5) (Urge-Vorsatz et al., 2006).

Figure 4. Trends in Coal-to-Electricity Efficiencies, 1990-2006 (In percent)
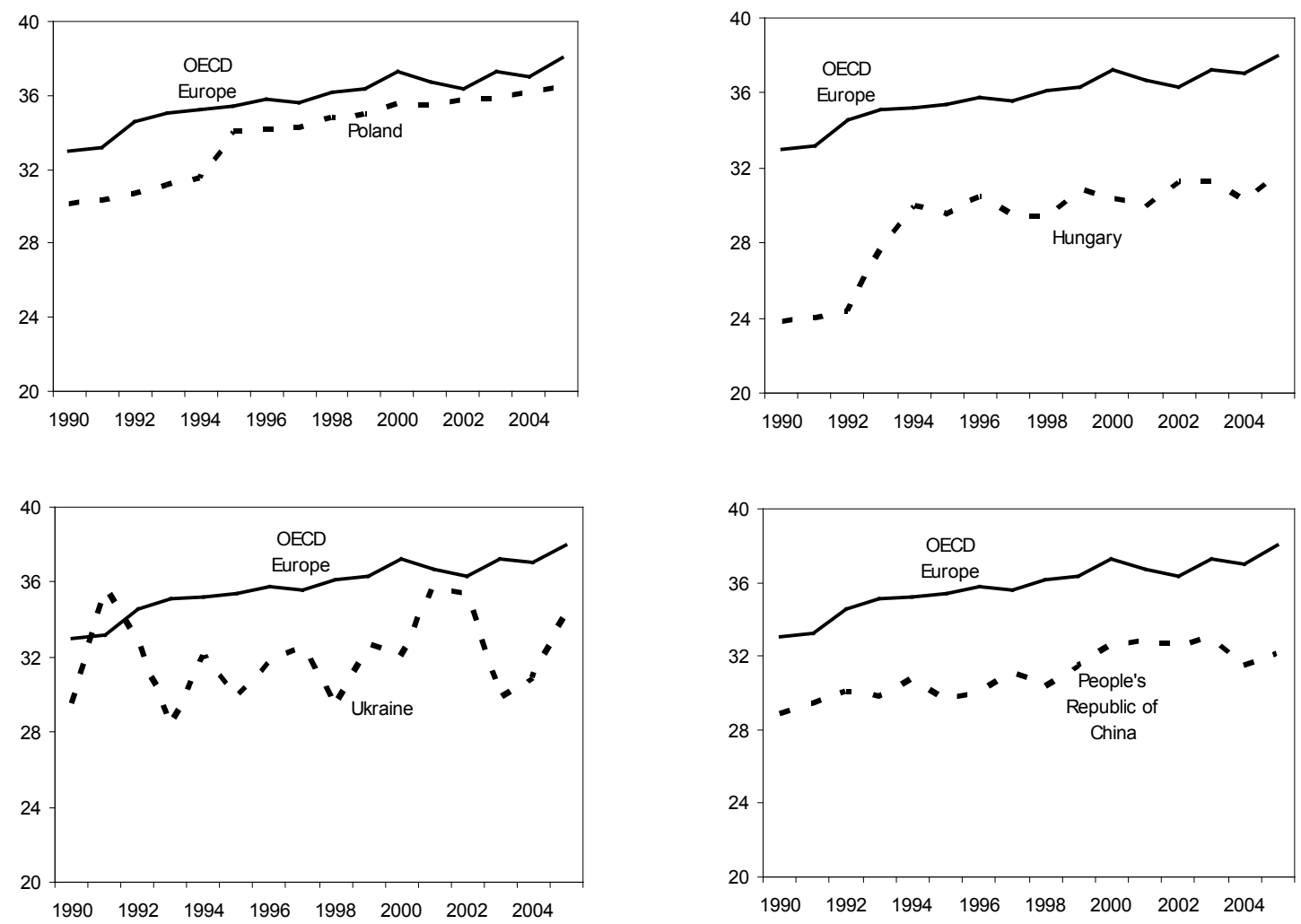

Sources: Maruyama and Eckelman (2009). 
Figure 5. Total Energy Intensity in Selected Countries in 1995 and 2006

(Kilogram of oil equivalent per 1000 Euro)
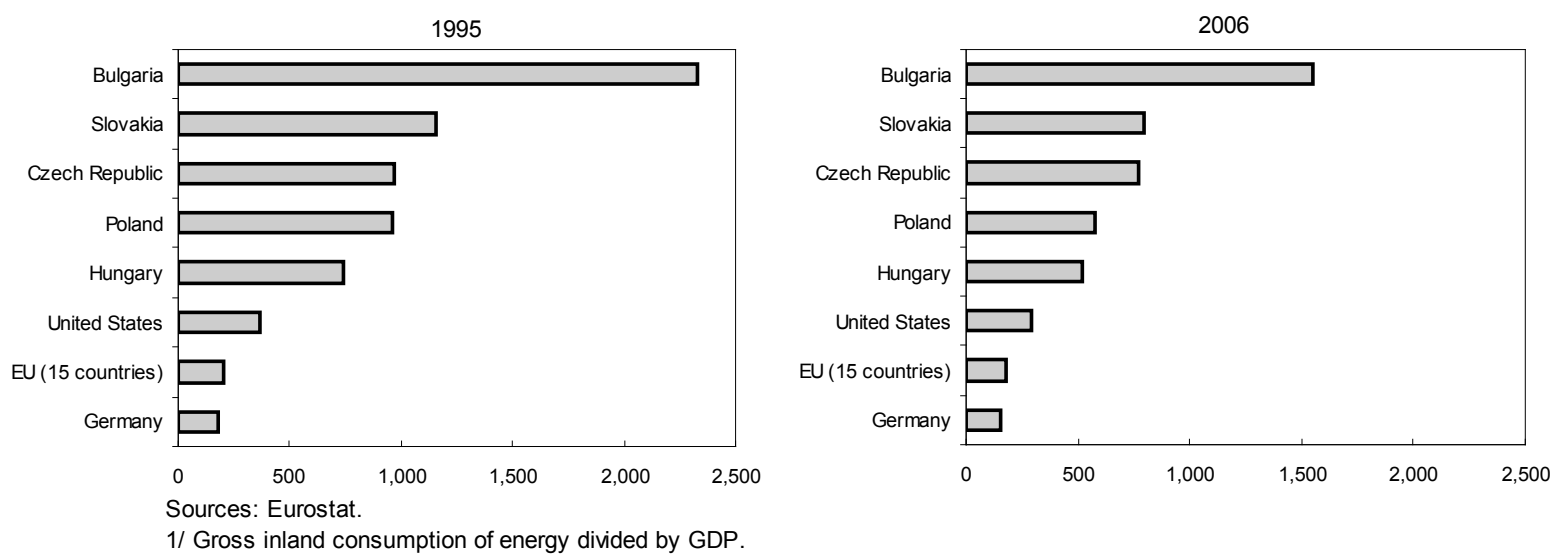

- When changing relative energy prices, energy reform can impact different energy producers in different ways and change relative intensities for different primary fuels (coal, oil, and gas, and renewable) (Hang and Tu, 2007).

- $\quad$ Higher primary fuel prices boost the performance and profitability of primary energy producers, while initially depressing the performance of non-energy nonfinancial enterprises (Tchaidze, 2007).

- $\quad$ Electricity prices must be increased in line with the increase in prices for primary fuels (which are inputs into electricity production). The increase in electricity prices allows for the higher cost of primary fuel prices possible and is necessary to finance the expansion of electricity generation needed to meet the rapid increase in demand in emerging markets (Zhao, 2001; Hang and Tu, 2007).

- $\quad$ Long-term demand for energy in developing and transition countries reforming their energy sectors should be expected to grow. Notwithstanding the long-term gradual convergence of energy intensity towards levels in the most energy efficient economies, the increase in energy demand resulting from income growth typically exceeds reductions in energy intensity (Markandya et. al., 2006).

14. Drawing on the international experience, energy price liberalization in Iran should include all primary energy prices as well as electricity prices to (a) minimize distortions as relative energy prices change, (b) allow the electricity sector to absorb higher gas and oil prices, and (c) finance new oil and gas production and electricity generation capacities. 


\section{Impact of Price Reform}

\section{Microeconomic Impact}

15. A significant increase in energy prices would have a profound and multidimensional impact on Iranian households and firms. Whether gradual or carried out in a single step, the increase in energy prices would (i) affect all energy users; (ii) increase production costs and prices of non-energy products; (iii) affect the absolute and relative competitiveness of domestic producers vis-à-vis producers of less/more energy intensive goods and services; (iv) change the demand patterns for almost all goods and services produced or imported into Iran through the substitution and income effects; and (v) alter the composition of Iranian exports away from energy intensive goods.

16. Higher energy prices are expected to raise the cost of living of all householdsurban and rural, rich and poor (Box 1) (Saboohi, 2001). The reforms would have a direct and indirect impact on energy consumption, cost of living, and welfare. Higher energy prices would also shift preferences to lower energy-intensive goods and services resulting in significant changes in household consumer baskets. For instance, higher gasoline prices will likely have both a substitution effect - toward the use of public transportation - and an income effect— - toward less overall traffic.

\section{Although the welfare of some households is likely to fall, the welfare of others} would increase. Compensatory payments to households that use relatively little energy (often the poor) may increase their real income and welfare. Similarly, households that place high value on time, the reliability of energy services, or the environment, may increase their welfare, as traffic congestion falls and the quality of energy services and the environment improves over time (Coady and Newhouse, 2005; World Bank, 2005a).

\section{Box 1. Estimated Impact of Energy Price Reform on Households in Iran}

Saboohi (2001) developed a methodology for estimating the direct and indirect impact of increased domestic energy prices on the cost of living of urban and rural households in different expenditure groups in Iran. He also estimated the net increases in the cost of living for different groups of households had energy prices been raised to their long-run marginal cost in late 1990s.

To reach long run marginal costs, the final energy prices for urban and rural households should have been raised about five-fold in late 1990s. As a result, the living expenses of an average urban and rural household would have increased by about 30 percent at the time, with a somewhat higher increase for rural households.

At the same time, revenues from higher energy prices would have allowed the government to compensate consumers for a large part of the increase in their expenditures following the price reform. The ultimate impact on household welfare would depend on the size of the compensation. 
18. At the enterprise level, higher energy prices would enhance the profitability of energy producers. The increase in the profitability of enterprises would be proportionate to the share of additional revenues that they are allocated. In the electricity sector, this would depend on whether electricity tariffs are allowed to increase to fully recover the higher cost of primary energy fuels and on the extent to which electricity generation would be liberalized (World Bank 2006a, 2007).

19. The impact of the energy price increase on the profitability of the non-energy, nonfinancial corporate sector would depend on the initial share of energy in the total value of inputs. It would also depend on the extent to which output prices could be increased to reflect the higher cost of inputs, and on the enterprises' ability to adopt energy saving measures and invest in more energy-efficient technologies. The impact of higher energy prices would therefore vary between different sectors of the economy, and within a specific sector, according to the energy intensity of individual producers and the final products. For instance, even though higher gasoline prices may have only a modest impact on the car industry in general, the impact on the individual product lines and producers of the most energy consuming automobiles could be very strong (Cameron and Schnusenberg, 2009).

20. The initial impact on the balance sheet and profitability of the financial sector is likely to be negative. Nonperforming loans are likely to increase as weaker non-financial companies as well as some households could seek deferment on their loan payment obligations.

\section{Macroeconomic Impact}

21. An increase in energy prices would have a direct and indirect impact on the price level by raising the price of energy products and energy-intensive goods and services. In addition, a gradual, rather than one-time, price increase could contribute to building inflationary expectations. At the same time, the reduction of government subsidies resulting from the increase in energy prices would — all other things being equal—increase fiscal savings, thereby helping to reduce inflation.

22. Large energy price increases would have a negative impact on GDP growth and employment in the short-term, even though the long term impact should be positive (Box 2) (Dhawan and Jeske, 2007; Finn, 2000). In the medium to long-term, higher energy prices would favor energy savings and the use of more energy efficient technologies, bringing the Iranian economy to a more optimal use of energy, and fostering growth (Apergis and Payne, 2009). 


\section{Box 2. Impact of Energy Price Increase on GDP and Employment}

While energy price shocks affect macroeconomic performance in numerous ways (Barsky and Kilian, 2004, and Kilian, 2008), the magnitude of the decline in output to an energy price shocks depends more on firms' share in energy consumption than households' share (Dhawan and Jeske, 2008). Quantifying the impact of energy price shocks on real GDP, employment and inflation is very difficult. Existing research indicates that output losses vary depending on the size of the price adjustment, duration of the reform, and mitigating policies.

\begin{tabular}{|l|l|l|l|l|}
\hline \multicolumn{1}{|c|}{ Country } & $\begin{array}{l}\text { Reference } \\
\text { period }\end{array}$ & \multicolumn{1}{|c|}{ Price increase } & Impact on GDP & \multicolumn{1}{|c|}{$\begin{array}{c}\text { Impact on } \\
\text { employment }\end{array}$} \\
\hline $\begin{array}{l}\text { Russian Federation, } \\
\text { (Braber and Tongeren, } \\
\text { 1996) }\end{array}$ & $\begin{array}{l}\text { Mid- } \\
1990 \mathrm{~s}\end{array}$ & $\begin{array}{l}\text { oil, gas, and coal: } \\
30-40 \text { percent }\end{array}$ & $\begin{array}{l}-1.2 \text { to }-1.6 \\
\text { percent }\end{array}$ & $\begin{array}{l}-1.1 \text { to }-1.3 \\
\text { percent }\end{array}$ \\
\hline $\begin{array}{l}\text { Moldova } \\
\text { (Baclajanschi et. al., } \\
\text { 2007) }\end{array}$ & $2006-07$ & $\begin{array}{l}\text { gas: } 200 \text { percent } \\
\text { electricity: } 80 \text { percent } \\
\text { oil price: } 10 \text { percent }\end{array}$ & $\begin{array}{l}2006:-5.1 \text { percent } \\
2007:-4.4 \text { percent }\end{array}$ & $\ldots$ \\
\hline $\begin{array}{l}\text { Ukraine } \\
\text { (World Bank, 2005b). }\end{array}$ & $2006-07$ & $\begin{array}{l}\text { gasoline: } 50 \text { percent } \\
\text { gas : } 123 \text { percent }\end{array}$ & $\begin{array}{l}2006:-8.6 \text { percent } \\
2007:-6 \text { percent }\end{array}$ & $\ldots$ \\
\hline $\begin{array}{l}\text { Washington State, USA } \\
\text { (Holland et. al., 2007) }\end{array}$ & $2003-06$ & crude oil: 124 percent & $\begin{array}{l}-4.9 \text { percent over } \\
\text { the period }\end{array}$ & $\begin{array}{l}-4.6 \text { percent } \\
\text { over the period }\end{array}$ \\
\hline
\end{tabular}

23. The increase in energy prices will lead to an increase in energy efficiency and a reduction of energy intensity. It is, however, difficult to predict the change in demand in response to such price increase (Box 3). Although the short-term price elasticity of demand for energy products in Iran and other Middle Eastern countries is very low, the very large price increases needed in Iran to bring domestic prices to their international levels are likely to dampen demand significantly, even in the short run.

24. The net impact on the government finances should be largely positive. On the positive side, a share of the revenues arising from higher prices could be transferred to the budget. In addition, lower consumption of energy products would reduce the need for imports of gasoline products and for compensatory transfers to refineries to offset their below-cost selling prices (Iwayemi et. al., 2009). On the negative side, higher energy prices are likely to result in lower tax revenues as economic activity slows down, and lead to an increase in social benefits (unemployment and welfare) and in the cost of energy supplies to the government. 


\section{Box 3. Islamic Republic of Iran: International Evidence of the Impact of Energy Price Reform on Economic Efficiency}

Bhattacharyyan and Blake (2009) estimated the short-run price elasticity of the demand for gasoline, diesel, kerosene, and fuel oil in Iran and several other Middle Eastern oil and gas producing countries. They showed that while the price elasticity is very low in the short-run, it increases in the medium- to long-run. Moreover, even with a very low price elasticity, the very large price increases needed to bring prices to their international levels is likely to dampen demand significantly. Davoudpour and Ahadi (2006) and Narayan and Smyth (2007) have similar results.

The relatively high long-run elasticity of demand for gasoline suggests that bringing gasoline prices to international level could significantly reduce Iran's domestic gasoline consumption and substantially decrease, if not eliminate, the need for gasoline imports, thereby contributing to improving Iran's trade balance and energy security. At the same time, the demand for other fuels may not decline in line with their elasticities, as the sharp reduction in use in private transport may stimulate demand for diesel-fueled public transport.

\begin{tabular}{|c|c|c|c|c|}
\hline \multicolumn{5}{|c|}{$\begin{array}{l}\text { Estimated price elasticity of demand for gasoline and diesel in } \\
\text { selected MENA countries }\end{array}$} \\
\hline & \multicolumn{2}{|c|}{ Short-run } & \multicolumn{2}{|l|}{ Long-run } \\
\hline & Gasoline & Diesel & Gasoline & Diesel \\
\hline Iran & -0.124 & -0.055 & -0.494 & -0.129 \\
\hline Kuwait & -0.143 & -0.404 & -0.303 & -2.694 \\
\hline Libya & -0.081 & 0.370 & -0.548 & 1.585 \\
\hline Qatar & -0.098 & -0.149 & -0.133 & $\ldots$ \\
\hline Saudi Arabia & 0.002 & -0.013 & 0.008 & -0.033 \\
\hline U.A.E & -0.188 & 0.020 & -1.064 & 0.163 \\
\hline
\end{tabular}

25. The external position is likely to improve sharply as the reduced domestic demand for energy would increase oil, gas, and electricity exports. At the same time, imports would decline due to the overall economic contraction and the reduction in the demand for gasoline. In addition, higher profits would enable the Iranian National Oil Company to increase investment and the supply of oil to the world markets, possibly impacting oil prices.

\section{E. Measures to Mitigate the Impact of the Reform}

\section{Microeconomic Measures}

26. The appropriate mix of supporting measures depends on the initial pre-reform conditions. For example, the impact of reforms on households will be less severe if households can benefit from a well-developed mass public transportation system, live in relatively energy efficient housing, use individual energy meters, and have a well-developed culture of energy saving and recycling (Urge-Vorsatz et. al., 2006). 
27. Protecting households from some of the extreme negative consequences of the price reform seems to be preferable to protecting enterprises. Ensuring that households are protected from the negative impact of the reforms through subsidies is essential not only to protect the poor, or ensure adequate support for the reform, but also to stimulate the demand necessary to uphold economic activity.

28. Households can be protected through the development of an efficient social safety net. The implementation of a safety net rests on (i) determining eligibility, (ii) choosing the form of household support (cash transfers or low-user tariff schemes), and (iii) calculating the value of household support (Navajas, 2009). Eligibility criteria should be established on the basis of a good database on households' characteristics before the price increase to minimize the financial plight of the poorest households. In the absence of an effective means-testing mechanism, a uniform compensation payment could be made to the whole population. Such a transfer would necessarily be progressive, benefiting the poor more than proportionally to their income (USAID, 2002).

29. The positive impact of reforms on energy producers depends on their ability to collect receivables. Often higher prices yield only limited additional revenues due to a decline in bill collection rates. An accumulation of private and public payment arrears in the energy sector can rapidly spill over into the entire economy (Fankhauser et. al., 2008). In addition, once the culture of nonpayment becomes entrenched, it can become very difficult to uproot. To limit this problem, public institutions must be fully funded and required to pay their energy bills; vulnerable households should receive compensation and be required to pay for energy; all households should be billed for their individual energy consumption as soon as possible and with high frequency; and, energy suppliers must be granted the right to disconnect nonpaying customers, whether public, households, or small or large commercial entities, and deploy measures to maintain high bill collection rates (such as pre-paid electricity or gas meters offered to customers with poor payment records).

30. Commercial energy users must face a hard budget constraint (World Bank 2005b). At the same time, they must be able either to earn a higher, market competitive, price for their output, or to change their production technology to reduce energy intensity, or to alter their product mix to reduce costs and maintain profit margins. Support measures, such as tax or cash support for restructuring, could help ensure their profitability while providing incentives to adopt more energy efficient technologies.

31. Lending standards and banking supervision must be strengthened to ensure that banks' balance sheets are not negatively affected. Avoiding a major deterioration of banks' lending portfolio is essential, particularly as a large number of borrowers could be unable to service debt as they devote an increasing share of their income to paying energy bills. New borrowers could also seek bank financing to cover their higher energy expenses. 
32. The success of the reform largely depends on the credibility of accompanying measures. For instance, in some countries, at least in the initial stages of energy sector reforms, price increases proved to be ineffective in reducing energy use because users managed to either avoid paying for energy, or were bailed out by state banks that were required to provide soft loans to large energy users. Typically, price increases for electricity were accompanied by reductions in bill collections from households and large enterprises. To restore payment discipline, some governments in reforming countries supported state bank lending to large enterprises in order to finance restructuring. Williams and Ghanadan (2006) also noted that the lack of success of reforms in some countries reflected mainly that they were too narrowly focused on finance and cost recovery instead of emphasizing a broader set of objectives, including service provision, public benefits, effective regulation, and social and political legitimacy.

\section{Countries that liberalized energy prices and moved fast on corporate} restructuring managed to achieve the largest gains in energy efficiency (Cornillie and Fankhauser, 2004). Conversely, reluctance and delays in enterprise restructuring delayed gains in reducing energy intensity. Government's inability to impose restructuring and privatization was typically accompanied by a soft budget constraint and resulted in further increases in energy intensity and waste following the increase in energy prices.

\section{Macroeconomic Measures}

34. Macroeconomic policies in support of the reform should ensure that energy users see the reform as non-reversible and face binding budget constraints that encourage active adjustment to the new price structure. Transparent and tight fiscal and monetary policies will limit market distortions and noise in market signals (Baclajanschi et. al., 2007).

\section{Successful reformers gear fiscal policies to establish hard budget constraints on} the economy. At the same time, leaving fiscal space for downside risks during the initial phase of the reform is always desirable, as it allows the government to provide sufficient support to the most vulnerable groups. In addition, a sufficiently large fiscal cushion should allow direct support from the budget rather than resorting to quasi-fiscal financing through the banking system that can introduce numerous distortions in the economy and ultimately undermine the reforms (Petri et. al. 2002, Saavalainen and ten Berge, 2006). ${ }^{1}$

\section{A tightening of monetary policy would be required to limit the secondary} effects of the price increase on the aggregate price level. The authorities should monitor closely developments in inflation, and adjust the monetary aggregates as needed (Chen,

\footnotetext{
${ }^{1}$ Sandu-Loisel (2007) contrast the long-term positive effects of abruptly cutting off subsidies to the less successful outcome of the gradual price and subsidy reform adopted by Romania during the 1990s in order to avoid a social crisis.
} 
2009). Estimating money demand and nominal GDP will pose some difficulties after energy prices are raised, as nominal GDP will surge when domestic energy sales are measured at the higher prices.

37. Exchange rate policy should support the reform by ensuring an adequate level of external competitiveness following the increase in prices. The reforms should also be accompanied by trade liberalization to ease access of restructuring enterprises and households to energy-efficient equipment and household appliances. In addition, a high degree of trade openness would reduce the magnitude of the pass-through of higher energy prices to domestic inflation, in particular when reforms are supported with tight monetary and exchange rate policies (Chen, 2009).

\section{F. Speed and Design of the Reform}

38. Reforming energy prices can be done through a single increase in tariffs and full liberalization of future price setting, or spread through several incremental increases in energy tariffs that eventually bring prices to their opportunity costs. Both reforms have advantages and disadvantages and carry risk. Single step reforms are preferred when the required price change is not overwhelmingly large and other supporting reforms to deal with the consequences of the price increase are in place. The risk of a sharp increase in

prices is that it may trigger immediate social discontent, and the reform may be reversed. A gradual implementation of the reform may be easier to manage. However, gradual reforms also allow opposition to build resistance to further price increases. The risk of a gradual reform is that it may end up with the first price increase, as the opponents to the reform could stop further implementation well before the benefits of the reform materialize.

39. Ideally, all energy prices should eventually be increased to opportunity cost levels (Box 4). The initial, administratively determined single-step or phased-in increase in prices could soon thereafter be replaced by a free market mechanism that would determine future price variations and ensure that prices continuously provide the necessary signals, incentives, and resources for further production capacity expansion to meet the growing demand in a rapidly growing economy (Wang et al., 2009). In addition, liberalization of the entire electricity market (generation, transmission, and distribution) may be critical to limit the long-term increase in electricity prices while ensuring an adequate flow of capital to the most competitive companies in the sector (Mohammadi, 2009).

40. Energy sales should be subject to the same VAT rate as other goods and services. However, to limit the impact of the sharp increase in energy prices, in some countries the authorities have opted to partially delay the implementation of energy taxation. Alternatively, a more modest increase in domestic prices can be accompanied by a single-step imposition of VAT and excises to ensure full budget funding during the reform period (Hossain, 2003). 


\section{Finally, energy sector reforms should include the establishment of a professionally staffed public regulatory body to oversee the energy sector. The new regulatory body should help bring the full benefits of market competition to the sector.}

\section{Box 4: Elements of design of price mechanism}

The determination of a new price mechanism requires setting:

(i) the target price: export f.o.b.; import c.i.f. price; or a fraction of the international price;

(ii) the speed of adjustment: single step; multi-step comprising periodic, pre-determined increases to the pre-set target; or multi-step periodic, pre-determined increases to the pre-set target adjusted for changes in the international price during the reform period; and

(iii) the future price setting mechanism. This includes decisions about:

(a) the selection of the decision maker (price change initiator): an independent regulatory body; an energy monopoly (producer or distributor); the government; or a market-driven mechanism.

(b) the periodicity of adjustment: either continuous, market based; at explicitly pre-determined intervals (weekly, monthly, quarterly); or ad hoc.

(c) the price base: market; explicit reference price (import or export); explicit price formula (import plus/minus); or indexed to CPI/PPI.

(d) the price base calculation: price at point in time of a single reference commodity or price index of a commodity composite; or a moving average of preceding period prices of a single reference commodity or of a price index of a commodity composite. 


\section{REFERENCES}

Alnatheer, Othman, 2005, "The Potential Contribution of Renewable Energy to Electricity Supply in Saudi Arabia,” Energy Policy 33, pp. 2298-2312.

Apergis, Nicholas and James E. Payne, 2009, "Energy Consumption and Economic Growth: Evidence from the Commonwealth of Independent States," Energy Economics, 31, pp. 211 216.

Awerbuch, S. and M. Berger, 2003, "EU Energy Diversity and Security: Applying Portfolio Theory to Electricity Planning and Policy-Making," International Energy Agency, available at http://www.awerbuch.com

Awerbuch, S. and R. Sauter, 2005, "Exploiting the Oil-GDP Effect to Support Renewables Deployment" The Freeman Centre, University of Sussex, Science and Technology Policy Research (SPRU), Paper No. 129 (January 2005), http://www.sussex.ac.uk/spru/

Baclajanschi, I, L. Bouton, H. Mori, D. Ostojic, T. Pushak, and E.R. Tiongson, 2007, "Rising Energy Prices in Moldova: Macroeconomic and Distributional Impact," Problems of Economic Transition 49/10, pp. 5-40.

Barsky, Robert B. and Lutz Kilian, 2004, "Oil and the Macroeconomy Since the 1970s," Journal of Economic Perspectives 18/4, pp. 115-134.

Belloumi, Mounir, 2009, "Energy Consumption and GDP in Tunesia: Cointegration and Causality Analysis,” Energy Policy 37, pp. 2745-2753.

Bhattacharyya, Subhes C. and Andon Blake, 2009, "Domestic Demand for Petroleum Products in MENA countries,” Energy Policy 37, pp. 1552-1560.

Braber, Rini and Frank van Tongeren, 1996, "Energy Price Reforms in Russia," Moct-MostEconomic Policy in Transitional Economies 6/2, pp. 139-162.

Cameron, Ken and Oliver Schnusenberg, 2009, "Oil Prices, SUVs, and Iraq: An Investigation of Automobile Manufacturer Oil Price Sensitivity," Energy Economics 31, pp. 375-381.

Chen, Shiu-Sheng, 2009, "Oil Price Pass-through into Inflation," Energy Economics 31, pp. 126-133. 
Coady, David, Moataz El-Said, Robert Gillingham, Kangni Kpodar, Paulo Medas, and David Newhouse, 2006, "The Magnitude and Distribution of Fuel Subsidies: Evidence from Bolivia, Ghana, Jordan, Mali, and Sri Lanka,” IMF Working Paper WP/06/247.

Cornillie, Jan and Samuel Fankhauser, 2004, "The Energy Intensity of Transition Countries," Energy Economics 26, pp. 283-295).

Davoudpour, Hamid and Mohammad Sadegh Ahadi, 2006, "The Potential for Greenhouse Gases Mitigation in Household Sector of Iran: Cases of Price reform/Efficiency Improvement and Scenario for 2000-2010," Energy Policy 34, pp. 40-49.

Dhawan, Rajeev and Karsten Jeske, 2006, "How Resilient Is the Modern Economy to Energy Price Shocks?" Federal Reserve Bank of Atlanta Economic Review, Third Quarter, pp. 21-32.

Dodonov, Boris, Petra Opitz, and Wolfgang Pfaffenberger, 2004, "How Much Do Electricity Tariff Increases in Ukraine Hurt the Poor?” Energy Policy 32, pp. 855-863.

Erdogdu, Erkan, 2007, “Regulatory Reform in Turkish Energy Industry: An Analysis,” Energy Policy 35, pp. 984-993.

Fankhauser, Samuel, Yulia Rodinova, and Elisabetta Falcetti, 2008, "Utility Payments in Ukraine: Affordability, Subsidies, and Arrears,” Energy Policy 36, pp. 4168-4177.

Farzanegan, Reza Mohammad and Gunther Markwardt, 2009, "The Effects of Oil Price Shocks on the Iranian Economy," Energy Economics 31, pp. 134-151.

Finn, Mary G, 2000, "Perfect Competition and the Effects of Energy Price Increases on Economic Activity," Journal of Money, Credit, and Banking 32, pp. 400-416.

Freund, Caroline and Christine I. Wallich, 1996, "The Welfare Effects of Raising Household Energy Prices in Poland," Energy journal 17/1, pp. 53-77.

Hang, Leiming and Meizeng Tu, 2007, “The Impacts of Energy Prices on Energy Intensity: Evidence from China, Energy Policy 35, pp. 2978-2988.

Hirschhausen von, Christian and Thomas W. Waelde, 2001, "The End of Transition: An Institutional Interpretation of Energy sector Reform in Eastern Europe and the CIS." MOCTMOST Economic Policy in Transitional Economies 11/3, 91-108.

Holland, David, Leroy Stodick, and Kethleen Painter, 2007, “Assessing the Economic Impact of Energy Price Increases on Washington Agriculture and the Washington Economy: A 
General Equilibrium Approach,” School of Economic Sciences Working Paper 2007-14, Washington State University.

Hossain, Shahabuddin Mosherraf, 2003, "Taxation and Pricing of Petroleum Products in Developing Countries: A Framework for Analysis with Application to Nigeria," IMF Working Paper WP/03/42.

IMF, 2008, "Subsidies in the Islamic Republic of Iran," in Islamic Republic of Iran: Selected Issues, Country Report No. 08/285, http://www.imf.org/external/pubs/cat/longres.cfm?sk=22282.0

Iwayemi, Akin, Adeola Adenikinju, and M. Adetunji Babatunde, 2009, "Estimating Petroleum Products Demand Elasticities in Nigeria: A Multivariate Cointegration Approach," Energy Economics, Article in Press.

Jafari, Houri H. and A. Baratimalayeri, 2008, "The Crisis of Gasoline Consumption in the Iran's Transportation Sector," Energy Policy 36, pp. 2536-2543.

Jannuzzi, De Martino Gilberto, 2005, "Power Sector Reforms in Brazil and its Impacts on Energy Efficiency and Research and Development Activities," Energy Policy 33, pp. 17531762.

Karbassi, A.R., M.A. Abduli, and E. Mahin Abdollahzadeh, 2007, "Sustainability of Energy Production and Use in Iran," Energy Policy 35, pp. 5171-5180.

Kilian, Lutz, 2008, “The Economic Effects of Energy Price Shocks," Journal of Economic Literature 46, pp. 871-909.

Kratena, Kurt, 2007, “Technical Change, Investment and Energy Intensity," Economic Systems Research 9/3, pp. 295-314.

Markandya, Anil, Suzette Pedroso-Galinato, and Dalia Streimikiene, 2006, "Energy Intensity in Transition Economies: Is There Convergence Towards the EU Average?" Energy Economics 28, pp. 121-145.

Maruyama, Naoko and Matthew J. Eckelman, 2009, "Long-term Trends of Electric Efficiencies in Electricity Generation in Developing Countries," Energy Policy 37, pp. 16781686.

Mehrara, Mohsen, 2007, "Energy Consumption and Economic Growth: The Case of Oil Exporting Countries," Energy Policy 35, pp. 2939-2945. 
Mehrara, Mohsen, 2008, "The Asymmetric Relationship between Oil Revenues and Economic Activities: The Case of Oil-Exporting Countries," Energy Policy 36, pp. 11641168

Mohammadi, Hassan, 2009, "Electricity Prices and Fuel Costs: Long-run Relations and Short-run Dynamics," Energy Economics 31, pp. 503-509.

Mostafaeipor, Ali and Neda Mostafaeipor, 2009, "Renewable Energy Issues and Electricity Production in Middle East Compared with Iran," Renewable and Sustainable Energy Review 13, pp. 1641-1645.

Narayan, Paresh Kumar and Russell Smyth, 2007, "A Panel Cointegration Analysis of the Demand for Oil in the Middle East," Energy Policy 35, pp. 6258-6265.

Navajas, Fernando H., 2009, "Engel Curves, Household Characteristics and Low-User Tariff Schemes in natural Gas," Energy Economics 31, pp. 162-168.

Okushima, Shinichiro and Makoto Tamura, 2009, "What Causes the Change in Energy demand in the Economy? The Role of Technological Change," Energy Economics, Article in Press.

Olivia, Susan and John Gibson, 2008, "Household Energy Demand and the Equity and Efficiency Aspects of Subsidy Reform in Indonesia,” Energy Journal 29/1, pp. 21-39.

Petri, Martin, Gunther Taube, and Aleh Tsyvinski, 2002, "Energy Sector Quasi-Fiscal Activities in the Countries of the Former Soviet Union," IMF Working Paper WP/02/60.

Saavalainen, Tapio and Joy ten Berge, 2006, "Quasi-Fiscal Deficits and Energy Conditionality in Selected CIS Countries," IMF Working Paper WP/06/43.

Saboohi, Y, 2001, “An Evaluation of the Impact of Reducing Energy Subsidies on Living Expenses of Households," Energy Policy 29, pp. 245-252.

Sandu-Loisel, Rodica, 2007, "Hardening Budget Constraints in Romania: An Approach by CGE Modeling,” Post-Communist Economies 19/1, pp. 93-115.

Sari, Ramazan and Ugur Soytas, 2007, "The Growth of Income and Energy Consumption in Six Developing Countries," Energy Policy 35, pp. 889-898.

Shafie-Pour, Majid and Mojtaba Ardestani, 2007, "Environmental Damage Costs in Iran by the Energy Sector," Energy Policy 35, pp. 4413-4423. 
Sobhiyah, M.H., and Y. Kh. Kashtiban, 2008, "Challenges of Iran's Energy Conversion Agreements in Future Competitive Market,” Energy Policy 36, pp. 2846-2849.

Tchaidze, Robert, 2007, "Quasi-Fiscal Deficits in Nonfinancial Enterprises," IMF Working Paper WP/07/10.

Urge-Vorsatz, Diana, Gergana Miladinova, and Laszlo Paizs, 2006, "Energy in Transition: From the Iron Curtain to the European Union,” Energy Policy 34, pp. 2279-2297.

USAID, 2002, "Addressing the Social Dimensions of Power Sector Reform in Developing Countries and Economies in Transition," A Report for the Office of Energy and Information Technology, U.S. Agency for International Development, Washington D.C., 20523.

Wang, Qiang, Huan-Ning Qui, and Yaoqiu Kuang, 2009, "Market-Driven Energy Pricing Necessary to Ensure China's Power Supply,” Energy Policy 37, pp. 2498-2504.

Williams, J.H. and Ghanadan, 2006, "Electricity Reform in Developing and Transition Countries: A Reappraisal," Energy 31, pp. 815-844.

World Bank, 2004, "Iran-Energy and Environment Review Policy Note.”

World Bank, 2005a, "Islamic Republic of Iran-Cost Assessment of Environmental Degradation."

World Bank, 2005b, “Ukraine: The Impact of Higher Natural Gas and Oil Prices.”

World Bank, 2006a, "Islamic Republic of Iran: Economic Growth in Iran: Opportunities and Constraints."

World Bank, 2006b, "Mainstreaming Environment in the Energy Sector- the Case of the Energy-Environment Review for Iran."

World Bank, 2007, "Islamic Republic of Iran: Power Sector Note.”

Zamani, M., 2007, "Energy Consumption and Economic Activities in Iran," Energy Economics 29, 1135-1140.

Zhao, Jimin, 2001, "Reform of China's Energy Institutions and Policies: Historical Evolution and Current Challenges," Belfer Center for Science and International Affairs Discussion Paper 2001-20, Energy Technology Innovation Project, John F. Kennedy School of Government, Harvard University. 